\title{
Vascular endothelial growth factor as an angiogenesis biomarker for the progression of autosomal dominant polycystic kidney disease
}

\author{
D.P. Martins ${ }^{1}$, M.A. Souza', M.E. Lopes Baitello' ${ }^{1}$, V. Nogueira', \\ C.I. Ferreira Oliveira ${ }^{1}$, M.A. de Souza Pinhel ${ }^{1}$, H.C. Caldas ${ }^{2}$, \\ M.A. Filho ${ }^{2}$ and D.R. Silva Souza ${ }^{1}$ \\ 'Departamento de Bioquímica e Biologia Molecular, \\ Faculdade de Medicina de São José do Rio Preto, SP, Brasil \\ ${ }^{2}$ Departamento de Medicina I, \\ Faculdade de Medicina de São José do Rio Preto, SP, Brasil \\ Corresponding author: D.P. Martins \\ E-mail: denise-martins@outlook.com
}

Genet. Mol. Res. 15 (1): gmr.15017623

Received September 10, 2015

Accepted November 6, 2015

Published January 26, 2016

DOI http://dx.doi.org/10.4238/gmr.15017623

ABSTRACT. Autosomal dominant polycystic kidney disease (ADPKD) is a hereditary nephropathy characterized by abnormal growth of epithelial cells. Genetic factors, including the vascular endothelial growth factor (VEGF) gene, play an important role in its progression. The main aim of this study was to evaluate the influence of VEGF-C936T polymorphism in the development and progression of ADPKD. In total, 302 individuals were studied and divided into two groups: G1 (73 patients with ADPKD) and G2 (229 individuals without the disease). Among the patients, $46(63 \%)$ progressed to end-stage renal disease (ESRD), and required hemodialysis and/or renal transplant. These patients were re-grouped into G1-A for progression analysis. A peripheral blood sample was obtained from all subjects; the DNA was extracted and the VEGF-C936T polymorphism analyzed using polymerase chain reaction/ 
restriction fragment length polymorphism. The significance level was set at $\mathrm{P}<0.05$. The homozygous wild-type genotype $(\mathrm{C} / \mathrm{C})$ was predominant in G1 $(78 \%)$ and G2 (79\%; P $=0.9249)$. We observed a significant reduction in the mean age of patients with the risk allele $(C / T+T / T=44.3 \pm 13.4$ years $)$ compared to the $\mathrm{C} / \mathrm{C}$ genotype $(52.2 \pm 9.6$ years; $\mathrm{P}=0.047)$ in $\mathrm{G} 1-\mathrm{A}$. In conclusion, the VEGF-C936T polymorphism does not discriminate patients from controls. However, the presence of the T allele appears to accelerate the progression of ADPKD, anticipating ESRD, thereby suggesting its importance in the prognosis of the disease. However, the importance role played by VEGF gene variants in different populations and larger sample sizes must be verified.

Key words: Progression; End-Stage Renal Disease; Polymorphism; VEGF

\section{INTRODUCTION}

Autosomal dominant polycystic kidney disease (ADPKD) is a progressive genetic disorder (Blanchette et al., 2015) characterized by abnormal growth of epithelial cells, formation of fluid-filled cysts, and interstitial fibrosis (Harris and Torres, 2014). Its prevalence, as determined by previous studies, is between 1/400 and 1/1000 live births in the population (Obeidova et al., 2014; Noël and Rieu, 2015). An estimated 600,000 individuals are affected by this disease (Fedeles et al., 2014). Approximately $4.4 \%$ of the patients with end-stage renal disease (ESRD) are believed to be carriers of ADPKD in the USA (Fedeles et al., 2014), compared to the 7.5\% in Brazil (Riella, 2010).

This type of nephropathy is a result of mutations in the polycystic kidney disease genes $P K D 1$ and PKD2. Mutations in the PKD1 gene are responsible for $85 \%$ of the ADPKD cases, with the remaining being attributed to mutations in PKD2 (Ali et al., 2015).

The diagnostic criteria for ADPKD include the presence of at least three (unilateral or bilateral) renal cysts in individuals aged 15-39 years, the presence of at least two cysts in each kidney in individuals aged 40-59 years, and the presence of at least four cysts in each kidney in individuals aged 60 years or more (Riella, 2010). Most patients show symptoms associated with renal cysts between the fourth and fifth decades of life. Currently, no treatment available that could check the progression of this disease (Riella, 2010); however, methods have been developed to control comorbidities, such as hypertension, pain, urinary tract infections, and cardiovascular complications (Braun, 2014).

The etiology of ADPKD can be explained by mutations in specific genes; on the other hand, the mechanism of cyst expansion and disease progression itself cannot be explained by single mutations. In this context, vascular endothelial growth factor, whose gene (VEGF) is mapped on human chromosome 6p23.3, can be highlighted as one of the key regulators of angiogenesis (Li et al., 2012).

Some studies have reported raised VEGF levels in fluids that fill the renal and liver cysts, as well as the presence of VEGF-A and VEGF-R2 receptors in the cystic epithelium (Reed et al., 2011; Huang et al., 2013). Moreover, cyst growth involves expansion of the renal vasculature (Raina et al., 2011). As angiogenesis may play a major role in renal cyst expansion, VEGF can be analyzed as a potential target.

Several hypotheses pertaining to molecular interactions and modifier genes, including $V E G F$, in ADPKD have been proposed. However, it is necessary to identify and understand the 
role of genetic factors in the development and progression of this disease. DNA polymorphisms, such as restriction fragment length polymorphisms (RFLP) and short tandem repeats, have been studied extensively to identify useful disease biomarkers. Single nucleotide polymorphisms (SNPs) are an additional type of genetic markers that have a significant impact on the diagnosis, treatment, and prevention of human genetic diseases (Li et al., 2012).

Here, we attempted to assess the influence of SNP C936T (rs3025039) in the VEGF gene and its association with the development and progression of ADPKD.

\section{MATERIAL AND METHODS}

\section{Ethics statement}

This study was approved by the Ethics Research Committee of Faculdade de Medicina de São José do Rio Preto (FAMERP) (CAEE: 00912812.6.0000.5415). All subjects were informed about the study, and confirmed their willingness to participate by signing an Informed Consent Form.

\section{Patient recruitment}

Three hundred and two individuals were recruited for this case control study between December 2012 and November 2014; the individuals were distributed into 2 groups: group 1 (G1) - 73 patients with ADPKD (51\% female), aged 12-83 years (53.3 \pm 14.0 years); group 2 (G2) - 229 individuals without ADPKD (59\% male), aged 30-84 years (51.8 \pm 13.4 years).

The patients were examined in the Specialty Clinic for Nephrology of Hospital de Base at FAMERP, Brazil, as well as in the Hemodialysis Centre of the same institution. All patients with positive ultrasound results were included, in compliance with the criteria presented by Riella (2010). The control group was selected at the Blood Centre of the institution, and individuals with a family history of kidney disease were excluded.

All participants were interviewed and asked to complete a questionnaire pertaining to their personal, clinical, and lifestyle history. Additionally, peripheral blood samples were collected to identify and evaluate theVEGF-C936T polymorphism.

\section{DNA preparation and polymerase chain reaction (PCR)}

DNA was extracted from leukocytes using the salting-out method (Salazar et al., 1998). The PCR mixture was composed of $0.5 \mu \mathrm{L}$ deoxynucleotide (each; $0.8 \mathrm{mM}$ ); $2.5 \mu \mathrm{L} 10 \mathrm{X}$ PCR buffer; $0.2 \mu \mathrm{L}$ Taq DNA polymerase $(5 \mathrm{U} / \mathrm{mL}) ; 1.0 \mu \mathrm{L} 25 \mathrm{mM} \mathrm{MgCl}_{2}$ (Thermo Fisher Scientific, São Paulo, Brazil); $3 \mu \mathrm{L} 2.5 \mathrm{mM}$ of each primer (Sigma Aldrich, São Paulo, Brazil); $10.8 \mu \mathrm{L}$ Milli-Q water (Millipore Milli-Q Synthesis, USA), and $2.5 \mu \mathrm{L} 0.2 \mu \mathrm{g}$ diluted genomic DNA. The reaction conditions for the amplification of polymorphic fragments in a thermocycler (Swift Maxi Thermal Cycler block- ESCO, Singapore) were set as follows: initial denaturation at $95^{\circ} \mathrm{C}$ for $5 \mathrm{~min} ; 30$ cycles of denaturation at $95^{\circ} \mathrm{C}$ for $60 \mathrm{~s}$, annealing at $59^{\circ} \mathrm{C}$ for $60 \mathrm{~s}$, extension at $72^{\circ} \mathrm{C}$ for $60 \mathrm{~s}$; and a final extension at $72^{\circ} \mathrm{C}$ for $10 \mathrm{~min}$ (Li et al., 2012).

\section{RFLP}

The PCR products, in $10 \mu \mathrm{L}$ aliquots, were digested with $0.5 \mu \mathrm{L}$ Nlalll restriction enzyme, 
$1.5 \mu \mathrm{L}$ enzyme buffer (Thermo Fisher Scientific) and $3 \mu \mathrm{L}$ Milli-Q water in a water bath (Poly Science, USA) at $37^{\circ} \mathrm{C}$ for $16 \mathrm{~h}$ ( $\mathrm{Li}$ et al., 2012); the digested products were electrophoresed on a $2.5 \%$ agarose gel under a constant electric current $(90 \mathrm{~V})$ for $90 \mathrm{~min}$. The gel was stained with Gel Red (Uniscience, São Paulo, Brazil) to allow the visualization of fragments for genotyping, using a photo-documented system (Alpha Innotech, Kasendorf, Germany). The electrophoretic patterns are shown in Figure 1.

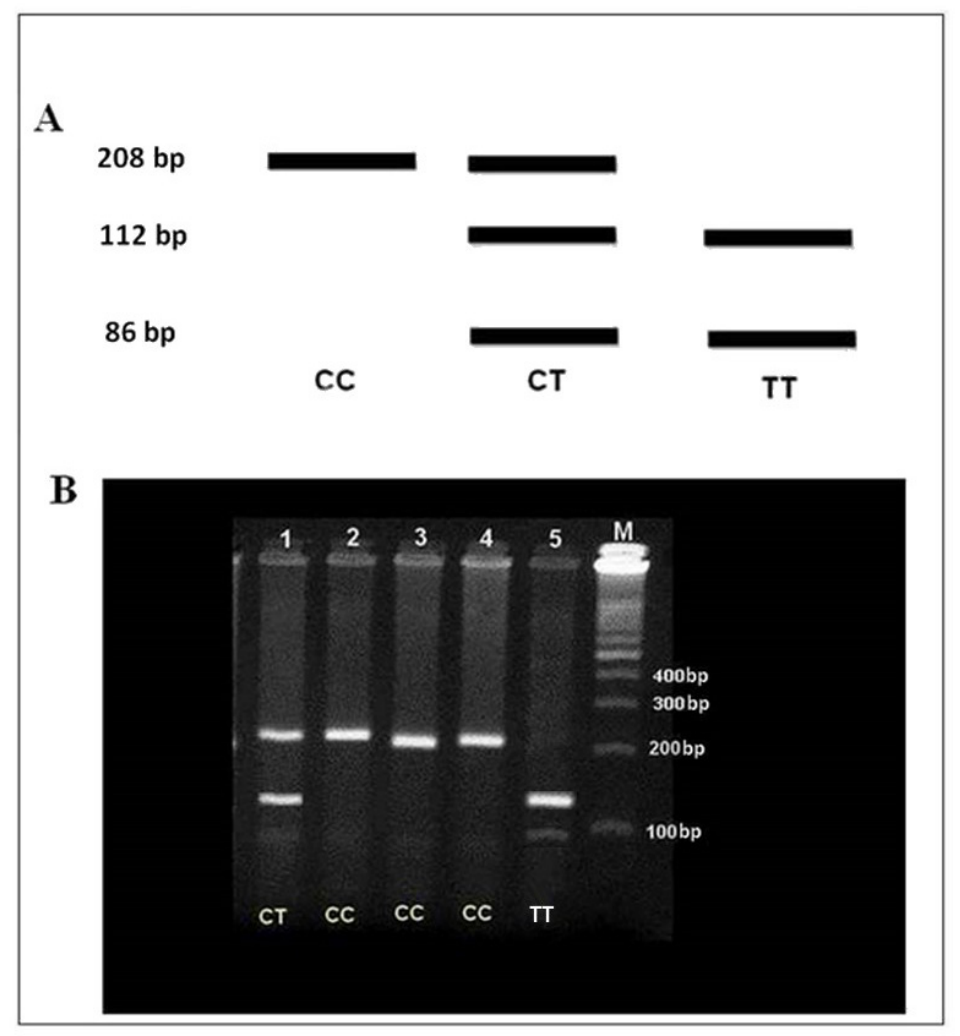

Figure 1. Band patterns of VEGF-C936T polymorphism. A. Band pattern of VEGF-C936T polymorphism showing the genotypes C/C [wild-type homozygote; 208 base pair (bp)], C/T (heterozygote; 208-, 122-, and 86-bp fragments), and $\mathrm{T} / \mathrm{T}$ (homozygous mutant; 122 - and 86 -bp fragments). B. $2.5 \%$ agarose gel with standards for genotypes $\mathrm{C} / \mathrm{T}, \mathrm{C} / \mathrm{C}$, and $\mathrm{T} / \mathrm{T}$ in lanes 1, 2-4, and 5, respectively, and a 100-1000-bp molecular marker in lane $\mathrm{M}$.

\section{Statistical analysis}

Qualitative variables, allele and genotype frequencies of SNPs, odds ratios and confidence intervals were analyzed by the Fisher exact test or chi-square test. The chi-square test was used to determine the deviations of the polymorphism from the Hardy-Weinberg equilibrium (HWE). The quantitative variables were analyzed by the $t$-test and Mann-Whitney test. All analyses were performed with a GraphPad InStat Software (version 3.06). The actuarial event-free survival curve (Kaplan-Meier) was analyzed in genotypes with at least one polymorphic allele (C/T and $\mathrm{T} / \mathrm{T}=$ $\left.\_/ \mathrm{T}\right)$, and in homozygous wild-type genotypes $(\mathrm{C} / \mathrm{C})$ requiring (or not) renal replacement therapy 
(RRT). The patients showing progression to ESRD and requiring RRT (G1-A = 46 patients) were also analyzed using the criteria listed by Reiterová et al. (2008), based on the age during the start of therapy. These patients were divided into three groups: rapid progressors (<45 years), intermediate progressors (45-63 years), and slow progressors (>63 years). Multiple logistic regression analysis was applied to evaluate the influence of independent variables (VEGF-_/T, hypertension, alcohol consumption, smoking, family history, and gender) on the progression of ADPKD to RRT. These data were analyzed using the SPSS statistics software (v.21; IBM, Armonk, NY, USA). The significance level was set at $P<0.05$.

\section{RESULTS}

Table 1. shows the demographic and clinical characteristics of patients and controls; the occurrence of hypertension in G1 (79\%) was compared to that in G2 (34\%; P < 0.0001).

\begin{tabular}{|c|c|c|c|c|c|c|c|}
\hline Variables & $\mathrm{G} 1(\mathrm{~N}=73)$ & $\%$ & $\mathrm{G} 2(\mathrm{~N}=229)$ & $\%$ & $P$ value & OR & $95 \% \mathrm{Cl}$ \\
\hline Hypertension & 58 & 79 & 77 & 34 & $<0.0001$ & 7.633 & $(4.06-14.34)$ \\
\hline Smokers & 13 & 18 & 52 & 23 & 0.4694 & 0.7375 & $(0.37-1.45)$ \\
\hline Diabetes mellitus & 4 & 5 & 9 & 4 & 0.5226 & 1.417 & $(0.42-4.75)$ \\
\hline Alcohol consumption & 19 & 26 & 36 & 16 & 0.0699 & 1.886 & $(1.00-3.55)$ \\
\hline Intracranial aneurysms & 1 & 1 & 3 & 1 & 1.0000 & 1.046 & $(0.11-10.22)$ \\
\hline Female gender & 37 & 51 & 95 & 41 & 0.2133 & 1.450 & $(0.85-2.46)$ \\
\hline
\end{tabular}

$\mathrm{SD}=$ standard deviation; $\mathrm{N}=$ number of subjects; $\mathrm{OR}=$ odds ratio; $\mathrm{Cl}=$ confidence interval; $\mathrm{P}=$ significance level $<0.05$.

Forty-six (63\%) patients in G1 who progressed to ESRD and required renal replacement therapy (mean age $=50.6 \pm 10.7$ years) were included in the subgroup G1-A. The remaining patients $(37 \%)$ were allocated to subgroup G1-B (Table 2$)$.

Table 2. Clinical characteristics of patients with autosomal dominant polycystic kidney disease (ADPKD) (G1) who progressed to ESRD and required renal replacement therapy (G1-A) and patients without progression (G1-B).

\begin{tabular}{|c|c|c|c|c|c|c|c|}
\hline Variables & $\mathrm{G} 1(\mathrm{~N}=73)$ & $\%$ & $\mathrm{G} 1-\mathrm{A}(\mathrm{N}=46)$ & $\%$ & $\mathrm{G} 1-\mathrm{B}(\mathrm{N}=27)$ & $\%$ & $\mathrm{P}$ value* $^{*}$ \\
\hline Hemodialysis & 32 & 44 & 32 & 69 & 0 & 0 & $<0.0001$ \\
\hline Transplant & 22 & 30 & 22 & 48 & 0 & 0 & $<0.0001$ \\
\hline Liver cysts & 25 & 34 & 14 & 30 & 11 & 41 & 0.5219 \\
\hline Back pain & 19 & 26 & 8 & 17 & 16 & 59 & 0.0006 \\
\hline $\begin{array}{l}\text { Family history of ADPKD } \\
\text { AGE (years) }\end{array}$ & 56 & 77 & 38 & 83 & 18 & 67 & 0.2044 \\
\hline Mean & 53.3 & & 50.6 & & 49.5 & & 0.7890 \\
\hline$\pm \mathrm{SD}$ & 14.0 & & 10.7 & & 18.0 & & \\
\hline
\end{tabular}

$\mathrm{SD}=$ standard deviation; $\mathrm{N}=$ number of subjects; $\mathrm{P}=$ significance level. ${ }^{*} \mathrm{G} 1-\mathrm{A} \times \mathrm{G} 1-\mathrm{B}$.

Table 3. shows the distribution of VEGF-C936T polymorphism, specifically the wild-type allele $\mathrm{C}$, in both groups $(0.89 ; \mathrm{P}=0.9290)$; additionally, the distribution of the homozygous wildtype $(\mathrm{C} / \mathrm{C})(\mathrm{G} 1=78 \%$ and $\mathrm{G} 2=79 \% ; \mathrm{P}=0.9249)$ and homozygous mutant $(\mathrm{T} / \mathrm{T})$ genotypes were analyzed; the latter was not observed in the members of G1 and G2. Both groups were in 
accordance with the HWE in the distribution of genotypes of VEGF-C936T (G1: $\chi^{2}=1.11$ and G2: $\left.\chi^{2}=3.29 ; P>0.05\right)$.

\begin{tabular}{|c|c|c|c|c|c|c|}
\hline Genotypes & G1 & $\%$ & G2 & $\%$ & $P$ value & OR $(95 \% \mathrm{Cl})$ \\
\hline С936T & $N=73$ & & $N=229$ & & & \\
\hline $\mathrm{C} / \mathrm{C}$ & 57 & 78 & 180 & 79 & 0.9249 & $0.9698(0.5122-1.836)$ \\
\hline $\mathrm{C} / \mathrm{T}$ & 16 & 22 & 49 & 21 & 0.9249 & $1.031(0.5446-1.952)$ \\
\hline$T / T$ & 0 & 0 & 0 & 0 & NC & NC \\
\hline Alleles & $N=146$ & abs. freq. & $N=458$ & abs. freq. & & \\
\hline C & 130 & 0.89 & 409 & 0.89 & 0.929 & $0.9734(0.5353-1.770)$ \\
\hline $\mathrm{T}$ & 16 & 0.11 & 49 & 0.11 & & \\
\hline HWE & 0.29 & & 0.07 & & & \\
\hline
\end{tabular}

$\mathrm{SD}=$ standard deviation; $\mathrm{N}=$ number of subjects; $\mathrm{OR}=$ odds ratio; $\mathrm{Cl}=$ confidence interval; $\mathrm{P}=$ significance level $<0.05 ; \mathrm{HWE}=$ Hardy-Weinberg equilibrium; VEGF = vascular endothelial growth factor; abs. freq. = absolute frequency.

A comparative analysis of the allele and genotype frequencies of VEGF-C936T was also performed, considering patients with familial and sporadic ADPKD; no association was observed between the two groups $(P>0.05$; Table 4$)$.

Table 4. Distribution of VEGF-C936T polymorphism in patients with autosomal dominant polycystic kidney disease (ADPKD) (G1) and control individuals (G2) based on the family history (FH) and sporadic (S) disease.

\begin{tabular}{|c|c|c|c|c|c|c|c|c|c|}
\hline \multirow{3}{*}{$\begin{array}{l}\text { Genotypes } \\
\text { C936T }\end{array}$} & \multicolumn{4}{|c|}{$\mathrm{G} 1(\mathrm{~N}=73)$} & \multirow{3}{*}{$\begin{array}{c}\text { P value } \\
a \times b\end{array}$} & \multicolumn{2}{|c|}{$\mathrm{G} 2(\mathrm{~N}=229)(\mathrm{c})$} & \multicolumn{2}{|c|}{$P$ value } \\
\hline & \multicolumn{2}{|c|}{$\mathrm{FH}(\mathrm{a})$} & \multicolumn{2}{|c|}{$S(b)$} & & & & & \\
\hline & $N=56$ & $\%$ & $N=17$ & $\%$ & & $\mathrm{~N}$ & $\%$ & $a \times c$ & $\mathrm{~b} \times \mathrm{c}$ \\
\hline $\mathrm{C} / \mathrm{C}$ & 42 & 75 & 15 & 88 & 0.3294 & 180 & 79 & 0.6871 & 0.5366 \\
\hline $\mathrm{C} / \mathrm{T}$ & 14 & 25 & 2 & 12 & 0.3294 & 49 & 21 & 0.6871 & 0.5366 \\
\hline $\mathrm{T} / \mathrm{T}$ & 0 & 0 & 0 & 0 & NC & 0 & 0 & $\mathrm{NC}$ & $\mathrm{NC}$ \\
\hline Alleles & $N=112$ & abs. freq. & $\mathrm{N}=34$ & abs. freq. & $a \times b$ & $N=458$ & abs. freq. & $a \times c$ & $\mathrm{~b} \times \mathrm{c}$ \\
\hline C & 98 & 0.87 & 32 & 0.94 & 0.3618 & 409 & 0.89 & 0.7063 & 0.5611 \\
\hline $\mathrm{T}$ & 14 & 0.13 & 2 & 0.06 & & 49 & 0.11 & & \\
\hline
\end{tabular}

$\mathrm{N}=$ number of subjects; $\mathrm{OR}=$ odds ratio; $\mathrm{Cl}=$ confidence interval; $\mathrm{P}=$ significance level $<0.05 ; \mathrm{VEGF}=$ vascular endothelial growth factor.

During the analysis, ESRD and the need for RRT were also considered. In this case, carriers of at least one polymorphic allele $(\mathrm{C} / \mathrm{T}+\mathrm{T} / \mathrm{T})$ during the start of therapy were of a lower mean age $(44.3 \pm 13.4$ years) compared to carriers of the homozygous wild-type genotype (C/C $=52.2 \pm 9.6$ years; $P=0.047)$; this difference was particularly observed in males $(41.5 \pm 14.6$ and $53.3 \pm 10.6$ years, respectively; $P=0.043$; Figure 2).

Patients whose disease had progressed to ESRD and required RRT $(\mathrm{G} 1-\mathrm{A}=46)$ were also analyzed using the criteria set by Reiterová et al. (2008). The age of ESRD was defined as the age during the start of renal replacement therapy. These patients were divided into three groups: rapid progressors ( $<45$ years), intermediate progressors ( $45-63$ years) and slow progressors $(>63$ years). However, the age limits of the three subgroups in both groups were the same ( $<45$ years, $45-63$ years, and $>63$ years; $P=0.6306$; Table 5 ). The Kaplan-Meier actuarial curve showed a similar probability of event-free survival (RRT) in the presence $(12.8 \%)$ or absence $(12.8 \%)$ of the polymorphic allele $(P=0.3943$; Figure 3$)$ among people aged up to 80 years. 


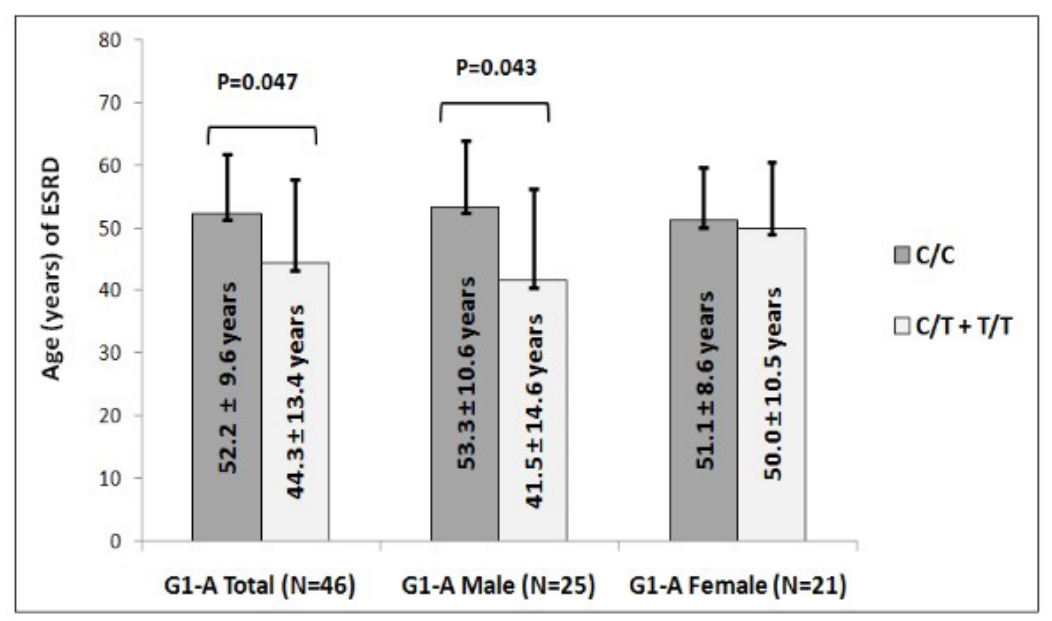

Figure 2. Mean ages and standard deviations of patients with autosomal dominant polycystic kidney disease and progression to ESRD expressing theVEGF-C936T genotype variants $C / C$ and $C / T+T / T$ (G1-A total); males and females are denoted by G1-A male and G1-A female, respectively.

Table 5. Distribution of VEGF-C936T polymorphism in patients with autosomal dominant polycystic kidney disease, progressing to end-stage renal disease (ESRD; G1-A) in a rapid, intermediate, or slow manner and control individuals (G2).

\begin{tabular}{|c|c|c|c|c|c|}
\hline \multirow{2}{*}{$\frac{\text { Groups }}{\mathrm{G} 1-\mathrm{A}(\mathrm{N}=46)}$} & \multicolumn{2}{|c|}{$\mathrm{C} / \mathrm{C}$} & \multicolumn{2}{|c|}{$\mathrm{C} / \mathrm{T}+\mathrm{T} / \mathrm{T}$} & \multirow[t]{2}{*}{$P$ value } \\
\hline & $N=37$ & $\%$ & $N=9$ & $\%$ & \\
\hline Rapid progressors $(\mathrm{N}=12)$ & 9 & 75 & 3 & 25 & 0.6777 \\
\hline Intermediate $(\mathrm{N}=28)$ & 22 & 79 & 6 & 21 & 1.0000 \\
\hline Slow progressors $(\mathrm{N}=6)$ & 6 & 100 & 0 & 0 & 0.3273 \\
\hline $\mathrm{G} 2(\mathrm{~N}=229)$ & $N=180$ & $\%$ & $\mathrm{~N}=49$ & $\%$ & \\
\hline All patients & 180 & 79 & 49 & 21 & 0.8459 \\
\hline
\end{tabular}

$\mathrm{N}=$ number of subjects; $\mathrm{P}=$ significance level $<0.05$; VEGF = vascular endothelial growth factor.

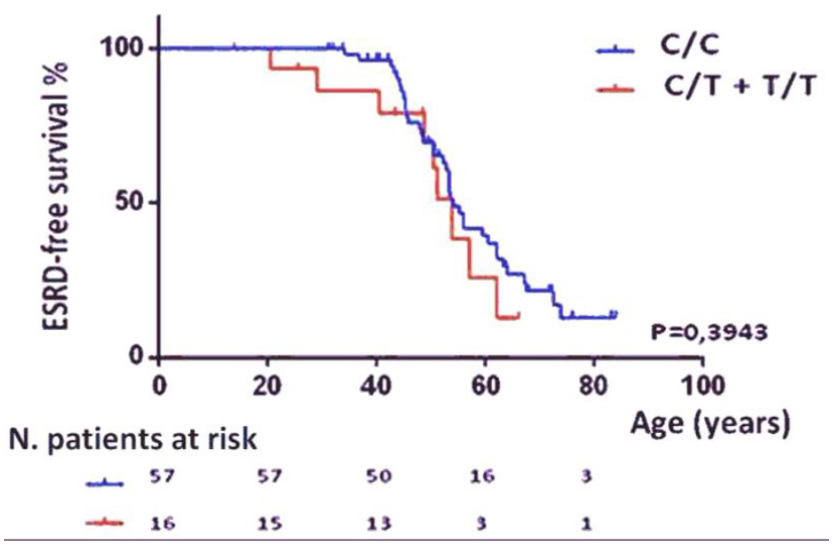

Figure 3. Event-free actuarial curve (Kaplan-Meier) (renal replacement therapy) based on the absence (C/C) or presence $(\mathrm{C} / \mathrm{T}+\mathrm{T} / \mathrm{T})$ of the mutant allele in patients with autosomal dominant polycystic kidney disease $(\mathrm{G} 1)$. 
A multiple logistic regression analysis showed the probability of progression to RRT in the presence or absence of certain assessed lifestyle habits such as smoking and alcohol consumption, comorbidity (hypertension), gender, family history of ADPKD, and genetic variants of VEGF-C936T. The following formula was thereby generated: $(R R T)=0.4282-0.1504$ (/IT VEGFC936T) +0.2142 (Hypertension) -0.2443 (Alcohol Consumption) +0.1884 (Smoking) +0.1766 (Family History) - 0.08025 (Gender). The results of this analysis showed no association between ADPKD and the respective variables $(P=0.2325)$.

\section{DISCUSSION}

Humans are believed to carry over a million distinct SNPs. The identification of SNPs is a new means to study the etiology of polygenetic disorders with complex inheritance patterns (Gurocak et al., 2015). ADPKD may progress to a stage where there is a need for hemodialysis and/or kidney transplant, and is influenced by modifier genes (Obeidova et al., 2014). VEGF, which is responsible for the survival, migration, proliferation, permeability, and dilation of blood vessels, may play an important role in the expansion of renal vasculature and cysts (Huang et al., 2013). However, this hypothesis remains to be verified. Many studies have attempted to correlate the expression of this gene and ADPKD; however, no study has focused on theVEGF-C936T polymorphism so far. However, we found no association between the VEGF-C936T polymorphism, or the VEGF haplotypes analyzed by Reiterová et al. (2008), and ADPKD in this seminal work.

The genotype and allele frequencies of VEGF-C936T were similar among patients with familial and sporadic ADPKD; this could be correlated to the similarities in clinical characteristics of the disease observed between the two groups by Neumann et al. (2012). In this study, only $13 \%$ of the patients were afflicted with sporadic disease, consistent with the numbers seen in previous reports $(10 \%)$; this was attributed to new mutations (Hazra et al., 2014).

Moreover, VEGF-C936T appeared to play a significant role during the onset of ESRD and during progression to hemodialysis and/or kidney transplantation. More than half the participants required RRT between the fourth and fifth decades of life, which was similar to the percentage seen in previous reports (Riella, 2010). Therefore, early identification of RRT based on carriers of the polymorphic allele $(\mathrm{C} / \mathrm{T})$ may contribute to the monitoring and prognosis of ADPKD, compared to the homozygous wild-type genotype (C/C).

Reiterová et al. (2008), in an analysis of the VEGF C-2578A polymorphism in ADPKD patients discovered a significant age difference between patients expressing the homozygous wildtype and heterozygous genotypes ( $42.7 \pm 3.5$ and $40.3 \pm 3.7$ years, respectively). This suggests a protective effect of the wild-type allele, delaying disease progression. On the other hand, increased production of VEGF in the renal tubules may accelerate fibrosis, cyst formation, and glomerular disease (Safrankova et al., 2011).

However, in this study, the actuarial analysis (Kaplan-Meier) of all patients with and without ESRD showed similar probabilities of event-free survival for both genotypes related with VEGFC936T (C/C vs C/T). This should be confirmed in a larger sample size, because a small number of individuals may limit the confidence of the results of this analysis. Additionally, we observed no differences among rapid, intermediate, and slow progressors, similar to the results obtained by Reiterová et al. (2008) in two other VEGF polymorphisms (A2578C and A1154G).

None of the variables analyzed with multivariate logistic regression were associated with ADPKD, which was corroborated by other studies. Kazancioglu et al. (2011) discovered a correlation 
between ADPKD and smoking in 35\% of all patients; on the other hand, Yildiz et al. (2014) observed no difference in alcohol consumption between the patients and controls. Hypertension, described as the most common clinical manifestation of ADPKD (Paul and Vanden Heuvel, 2014), was observed in $79 \%$ of the patients, which was similar to the percentage $(71 \%)$ reported by Taylor et al. (2005). However, hypertension showed no relevance in the regression analysis, although it has been previously considered as the most common clinical manifestation of ADPKD (Kazancioglu et al., 2011), and has been related to disease progression (Ozkok et al., 2013).

\section{CONCLUSIONS}

In this study, VEGF-C936T polymorphism did not differentiate patients from controls. However, the presence of allele T appeared to accelerate the progression of ADPKD and was an anticipatory marker for ESRD, which suggests its importance in the prognosis of the disease. It is therefore necessary to confirm the real importance of VEGF gene variants in the manifestation and progression of ADPKD in different populations and larger sample sizes.

\section{Conflicts of interest}

The authors declare no conflict of interest.

\section{ACKNOWLEDGMENTS}

The authors would like to thank all patients who participated in this study.

\section{REFERENCES}

Ali H, Hussain N, Naim M, Zayed M, et al. (2015). A novel PKD1 variant demonstrates a disease-modifying role in trans with a truncating PKD1 mutation in patients with autosomal dominant polycystic kidney disease. BMC Nephrol. 16: 26.http:// dx.doi.org/10.1186/s12882-015-0015-7

Blanchette CM, Liang C, Lubeck DP, Newsome B, et al. (2015). Progression of autosomal dominant kidney disease: measurement of the stage transitions of chronic kidney disease. Drugs Context 4: 212275.http://dx.doi.org/10.7573/dic.212275

Braun WE (2014). Advances in autosomal dominant polycystic kidney disease-2014 and beyond. Cleve. Clin. J. Med. 81: 545556.http://dx.doi.org/10.3949/ccjm.81gr.14001

Fedeles SV, Gallagher AR and Somlo S (2014). Polycystin-1: a master regulator of intersecting cystic pathways. Trends Mol. Med. 20: 251-260.http://dx.doi.org/10.1016/j.molmed.2014.01.004

Gurocak S, Konac E, Ure I, Senol C, et al. (2015). The impact of gene polymorphisms on the success of anticholinergic treatment in children with overactive bladder. Dis. Markers 2015: 732686.http://dx.doi.org/10.1155/2015/732686

Harris PC and Torres VE (2014). Genetic mechanisms and signaling pathways in autosomal dominant polycystic kidney disease. J. Clin. Invest. 124: 2315-2324.http://dx.doi.org/10.1172/JCl72272

Hazra A, Siderits R, Rimmer C and Rolleri N (2014). Autopsy report with clinical and pathophysiologic discussion of autosomal dominant adult polycystic kidney disease. Case Rep. Urol. 2014: 727580.http://dx.doi.org/10.1155/2014/727580

Huang JL, Woolf AS and Long DA (2013). Angiogenesis and autosomal dominant polycystic kidney disease. Pediatr. Nephrol. 28: 1749-1755.http://dx.doi.org/10.1007/s00467-012-2305-7

Kazancioglu R, Ecder T, Altintepe L, Altiparmak MR, et al.; Turkish Society of Nephrology Polycystic Kidney Disease Working Group (2011). Demographic and clinical characteristics of patients with autosomal dominant polycystic kidney disease: a multicenter experience. Nephron Clin. Pract. 117: c270-c275.http://dx.doi.org/10.1159/000320745

Li Y, Liang J, Liu X, Liu H, et al. (2012). Correlation of polymorphisms of the vascular endothelial growth factor gene and the risk of lung cancer in an ethnic Han group of North China. Exp. Ther. Med. 3: 673-676.

Neumann HP, Bacher J, Nabulsi Z, Ortiz Brüchle N, et al. (2012). Adult patients with sporadic polycystic kidney disease: the importance of screening for mutations in the PKD1 and PKD2 genes. Int. Urol. Nephrol. 44: 1753-1762. PubMed http:// 
dx.doi.org/10.1007/s11255-012-0125-0

Noël $\mathrm{N}$ and Rieu P (2015). Pathophysiologie, épidémiologie, présentation clinique, diagnostic et options thérapeutiques dans la polykystose rénale autosomique dominante. Nephrol. Ther. 11: 213-225.http://dx.doi.org/10.1016/j.nephro.2015.04.001

Obeidova L, Elisakova V, Stekrova J, Reiterova J, et al. (2014). Novel mutations of $P K D$ genes in the Czech population with autosomal dominant polycystic kidney disease. BMC Med. Genet. 15: 41.http://dx.doi.org/10.1186/1471-2350-15-41

Ozkok A, Akpinar TS, Tufan F, Kanitez NA, et al. (2013). Clinical characteristics and predictors of progression of chronic kidney disease in autosomal dominant polycystic kidney disease: a single center experience. Clin. Exp. Nephrol. 17: 345-351. http://dx.doi.org/10.1007/s10157-012-0706-3

Paul BM and Vanden Heuvel GB (2014). Kidney: polycystic kidney disease. Wiley Interdiscip. Rev. Dev. Biol. 3: 465-487.http:/l dx.doi.org/10.1002/wdev.152

Raina S, Honer M, Krämer SD, Liu Y, et al. (2011). Anti-VEGF antibody treatment accelerates polycystic kidney disease. Am. J. Physiol. Renal Physiol. 301: F773-F783.http://dx.doi.org/10.1152/ajprenal.00058.2011

Reed BY, Masoumi A, Elhassan E, McFann K, et al. (2011). Angiogenic growth factors correlate with disease severity in young patients with autosomal dominant polycystic kidney disease. Kidney Int. 79: 128-134.http://dx.doi.org/10.1038/ ki.2010.355

Reiterová J, Obeidová H, Lenícek M, Stekrová J, et al. (2008). Influence of VEGF polymorphism on progression of autosomal dominant polycystic kidney disease. Kidney Blood Press. Res. 31: 398-403.http://dx.doi.org/10.1159/000180269

Riella MC (2010). Princípios de nefrologia e distúrbios hidroeletrolíticos. 5. eds. Rio de Janeiro: Guanabara Koogan. 788-803.

Safránková H, Merta M, Reiterová J, Stekrová J, et al. (2011). The influence of vascular endothelial growth factor (VEGF) polymorphism on the progression of chronic glomerulonephritides. Folia Biol. (Praha) 57: 145-150.

Salazar LA, Hirata MH, Cavalli SA, Machado MO, et al. (1998). Optimized procedure for DNA isolation from fresh and cryopreserved clotted human blood useful in clinical molecular testing. Clin. Chem. 44: 1748-1750.

Taylor M, Johnson AM, Tison M, Fain P, et al. (2005). Earlier diagnosis of autosomal dominant polycystic kidney disease: importance of family history and implications for cardiovascular and renal complications. Am. J. Kidney Dis. 46: 415-423. http://dx.doi.org/10.1053/j.ajkd.2005.05.029

Yildiz A, Gul CB, Ersoy A, Asiltas B, et al. (2014). Arterial dysfunction in early autosomal dominant polycystic kidney disease independent of fibroblast growth factor 23. Iran. J. Kidney Dis. 8: 443-449. 